\title{
シンポジウム 細菌感染症の化学療法
}

（2）内科系感染症の化学療法の問題点

ii ) 胆道感染症の化学療法

東京大学医科学研究所内科

国井乙彦

\section{SYMPOSIUM ON THE GHEMOTHERAPY OF BACTERIAL INFECTION \\ (2) POINTS AT ISSUE IN THE CHEMOTHERAPY OF BACTERIAL INFECTION IN THE FIELD OF INTERNAL MEDICINE}

ii) A STUDY ON THE CHEMOTHERAPY OF THE BILIARY INFECTION

Otohiko KUNII, MD

The Department of Internal Medicine, The Institute of Medical Science, The University of Tokyo

はじめに

胆道感染症の化学療法に際して, 他葴器感染症 と同様に，原則的に，できるだけ正確に原因菌を 把握し，その化学寮法剤に対する感受性を調べ, 感受性良好な薬剤のうち, さらに藏器親和性（胆 汁内移行性）が良好でから副作用の少ない化学療 法剤を選択使用することが重要である。原因菌不 明の場合には最新の統計的知見に基ついて検出頻 度の高い菌を目標として, 耐性頻度が少なくかつ 広域スペクトルの化学療法剤を選択することが望 ましい。

\section{I. 原因菌}

内科臨床では，できるだけ無菌的な十二指腸ソ ソデ法によつてB胆汁を採取し，その培養で得ら れた細菌(口腔内常在細菌を除く)を一応原因菌之 考え，化学療法の対象とすることが多いのが現状 である，これが本症の一次的な原因か否かについ てはな招解決すべき問題が残されているが，本症 の成立に少なくともこれら細菌の二次的役割を肯 定し，この菌を目標とした化学療法による臨床的 経過と菌の消長に平行関係が認められるという先 人の多くの業績(1) に基づいているすのである.
胆道感染症の診療に際し, 胆䧆胆汁中の細菌を 検查することは望ましいことではあるが，内科領 域では毎常可能とは限らず，むしろ不可能な場合 が少なくない，そこで胆道疾患症例の手術前のB 胆计内細菌と手術時の胆衰胆计中細菌を対比して みると, 胆衰胆管の結石その他による閉塞と, 化 学療法による菌交代現象を除外すれば，胆変胆汁 中の細菌はかなりの程度に十二指腸 B 胆汁中に見 出される.しかしこの逆は必ずしる成立せず，十 二指腸 B 胆汁中の細菌は必ずしも胆硬胆汁中に見 出されるとは限らない。

古くから胆亭壁，胆恶胆汁，胆管胆汁等からの 分離菌の報告が多数みられるが，大部分の報告に 括いて, E. coli，Klebsiella等のグラム陰性腸内 桿菌が第 1 位であることに変りはない1) 。表 1 は1959 1976年の約18年間の十二指腸夜 B 胆汁に ついての細菌検查成績を示したものであるが，や はりE. coli, Klebsiella, Enterobacter, Proteus, Pseudomonas等を中心とするグラム陰性桿菌が 70〜80\%以上を占めており，この状況はこの18年 間大きな変動は認められない。

このような主要起炎菌は耐性菌ことに多剤耐性 
表 1. Bacteria isolated from the duodenal juice.

\begin{tabular}{|c|c|c|c|c|c|c|c|}
\hline & 1959 & 65 & $63-6 ?$ & 68 & 69 & $68-72$ & $73-76$ \\
\hline Hospital* & A & $B$ & $C$ & A & A & $\mathrm{C}$ & $c$ \\
\hline E.coli & \multicolumn{2}{|c|}{$30.1^{\%} / 28.4$} & 34.8 & 34,2 & 37.0 & 32.8 & 27.6 \\
\hline Kleb. & \multirow{2}{*}{17.2} & \multirow{2}{*}{9.9} & 34.8 & \multirow{2}{*}{18.9} & \multirow{2}{*}{32.1} & 23.9 & 30.1 \\
\hline Enterobact & & & 4.7 & & & 13.4 & 9.8 \\
\hline Proteus & 2.3 & 3.7 & 1.2 & 5.9 & 2.7 & 1.5 & 3.2 \\
\hline Pseudo. & 1.2 & & 3.5 & 0.7 & 1.4 & 6.0 & 7.3 \\
\hline Salmo. & 0.8 & 1.2 & 1.2. & 0.7 & & 1.5 & 4.1 \\
\hline Other GNB & 21.8 & 28.4 & 1.2 & 28.2 & 14.4 & 6.0 & 8.9 \\
\hline Staph. & 16.4 & 2.5 & 6.9 & 6.2 & 6.2 & 1.5 & 0 \\
\hline Strept. & 6.3 & 19.8 & 4.7 & 5.2 & 6.2 & 3.0 & 6.5 \\
\hline Other $\mathrm{CPC}$ & 1.6 & 4.9 & 4.7 & & & 6.0 & 0.8 \\
\hline Others & 2.3 & 1.2 & 2.3 & & & 4.4 & 1.6 \\
\hline Total No. & 256 & 81 & 86 & 307 & 146 & 67 & 123 \\
\hline & Hospi & & & \# & & & \\
\hline & $\begin{array}{l}\text { A : } \\
\text { B : } \\
\text { C : }\end{array}$ & $\begin{array}{l}\text { Unive } \\
\text { Unive } \\
\text { Institu } \\
\text { Unive }\end{array}$ & $\begin{array}{l}\text { rsity } \\
\text { rsity } \\
\text { ute of } \\
\text { rsity }\end{array}$ & $\begin{array}{l}\text { f Toky } \\
\text { Hokk } \\
\text { Medica } \\
\text { f Tokyo }\end{array}$ & $\begin{array}{l}\text { aido } \\
\text { a Sci }\end{array}$ & & \\
\hline
\end{tabular}

株の検出頻度が高いので, 化学療法に際し, その 薬剤感受性が当然重要な問題である.

E coli, Klebsiellaの各抗生物質に 対する 耐性 菌の分離頻度を三濃度ディスク法で調べてみると ((一)と（十）を耐性とした), E. coliではかつ てのいかゆる常用抗生剤, SM, CP, TC等に対す る耐性菌の分離頻度は約50〜60\%以上を占め, 近 年多用傾向のあるCER, ABPC, CBPC, KM等に対 する耐性菌る増加傾向にある点は注意を要する。

Klebsiellaについても同様の傾向が認められる が, $\mathrm{ABPC} \mathrm{PBPC}$ 等の広域スペクトル合成PCに は自然耐性菌がきわめて高率にみられることは E. coliとの大きな相違点であることに留意する 必要がある。

最近の 5 年間に十二指腸液 B 胆汁から分離され た主要起炎菌の化学療法剂に対する感受性を表 2

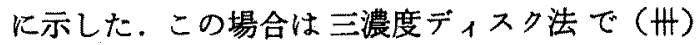
と（\#）を感性としたものである。これらの諸

表 2. Sensitivity of individual organisms in the bile.

\begin{tabular}{|c|c|c|c|c|c|c|}
\hline & $\mathrm{GM}$ & $A B P C$ & $\mathrm{CBPC}$ & CER & $C P$ & TC \\
\hline $\begin{array}{l}\text { Conc, of Ant1- } \\
\text { biotics in the } \\
\text { Bise }(\mu \mathrm{g} / \mathrm{ml})\end{array}$ & 5 & 5 & 20 & 10 & 10 & 10 \\
\hline E. coll & $27100 \%$ & 28 & $26 \quad 65.4 \%$ & $\begin{array}{l}28 \\
89.3 \%\end{array}$ & ${ }^{27} 70.4 \%$ & $2867.9 \%$ \\
\hline Klebsiella & ${ }^{30}{ }_{100 \%}$ & $267.7 \%$ & $85.0 \%$ & ${ }^{33} 75.8 \%$ & ${ }^{33} 75.8 \%$ & $3275.0 \%$ \\
\hline Enterobacter & ${ }^{7} 100 \%$ & ${ }_{16.7 \%}$ & ${ }^{6} 16.7 \%$ & ${ }^{7} 28,6 \%$ & ${ }^{7} 57.1 \%$ & ${ }^{7} 28.6 \%$ \\
\hline Ps. aeruginosa & ${ }^{7} 85.7 \%$ & & ${ }^{5} 60.0 \%$ & & & \\
\hline
\end{tabular}

菌すなわちE. coli, Klebsiella, Enterobacter, Ps. aeruginosa等にGMは最も良好な感受性を示し，次 いでCER，CP，TCさらにABPC，CBPCとなつて いるが，KlebsiellaはABPCやCBPCに感性がき めて低く, Ps. aeruginosaはGM, CBPC以外のむ のに耐性である。

\section{I. 化学療法剂の胆汁内移行}

各化学療法剂の胆汁人の排泄について，腎クリ アランスと同様の考えで正常イヌについて計算し た成績によると吕，PC系， macrolide系抗生剤， RFP等で高値を示し次いでCP, TCで，KM，AK $\mathrm{M}, \mathrm{GM}$ 等のaminoglycoside系抗生剂は最も低い值 を示している。

胆汁内移行の良好な $\mathrm{ABPC}$ ，中等度のCP，不良 のKMの三種の抗生物質を用い，この三者の薬剤 に注ぼ同じMICを示す大腸菌を用いたイヌの実 験的胆衰炎化対する治療効果をみた実験成績で は，胆汁内移行の最すずれているABPCの胆道 内除菌効果が最む著明で，移行中等度 のCPでは 菌数減少がみられたが，移行不良のKMでは全く 効果が認められず，除菌効果 と胆汁内移行性は 明白な平行関係が認められる6)，GMは胆道感染 症の主要起炎菌に対しすぐれた抗菌力を有するこ とは前述したが，GMの胆汁内移行性はKMと同 様に不良である。この実験成績が示す如く， GM む $\mathrm{KM}$ と同様にたとえ起炎菌にすぐれた抗菌力を 有する薬剤であつても，胆汁内移行が悪ければ胆 道内除菌効果が著しく劣ることになるので，化学 療法剂の選択に際しこの胆汁内移行性にむ充分注 意する必要がある。

さらに，この胆汁内移行は胆道閉塞性障害や， 高度の肝障害を伴うものでは，本来移行性良好な 薬剤でも著しく低下してくる，演者らもラットを 用い実験的四塩化炭素肝障害の場合には， ABPC やCEZの胆汁内排泄が著明に低下することを示し た. Mortimer, $\mathrm{PR}^{7}$ らす臨床例について, 胆襄胆 管あるいは総胆管に閉塞性障害のある例ではAB PCの胆汁内移行が著明に低下することを報告し ている.CLDMについても同様の報告解がみられ 
る。

\section{III. 化学療法剂の代謝}

近年化学療法剂も生体内で種々の代謝を受ける ことが次第に明らかになつてきつつあり，一般に 代謝物の生物学的活性は低下ないしは消失するむ のが多い. 例えばpenicillinはpenilloic acidやpenicillenic acid等になり抗菌活性は消失するし， CET, CEG, CEP, RFP等はdesacetyl体となり抗 菌活性は低下寸る。

胆道感染症では肝障害を伴うことが少なくな い.一般に障害肝では薬物の代謝が低下寸るが， 化学療法剈す同様である。

ラットを用いCETについて胆汁内のCETおよび その代謝物DACET (desacetyl cephalothin) の濃 度を薄凮クロマトグラフィーおよびbioautography で測定しCET/DACETの比率を図 1に示した。正 常対照群に比して四塩化炭素肝障害群ではこの 比率が上昇し，CETの肝に打ける代謝が低下して いることが明らかで, 尿についても同様の傾向が 認められる。なおとトと類似の代謝を行ならモル モットを用いて，RFPの代謝についても同様に， 四塩化炭素肝障害群で代謝が低下している成績が 得られた。

以上のように, 肝・胆道障害時には排泄の障害 と代謝障害によつて，とくに肝・胆道を主要排泄 経路とする化学療法剤においては, 原物質が体内
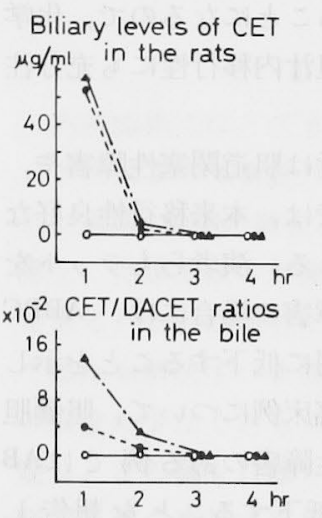

Biliary levels of DACET
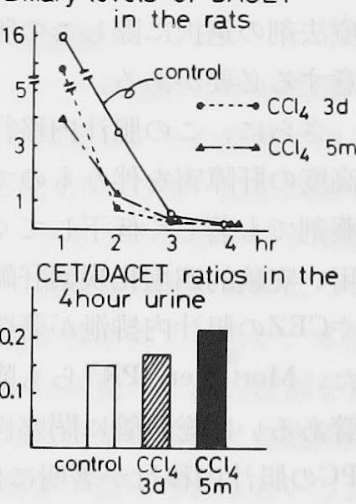

図 1
に高濃度に長く維持されることになり，胆道系以 外の場における楽効を求める立場からすれば有利 となるが，一方ではそれだけ一層副作用発現の可 能性が大きくなるので，この点に対する考虑も必 要である.

\section{IV. 肝障害時の化学療法が肝機能に及ほす影} 部

胆道感染症に肝障害を伴うことは少なくない。 そこで, 肝障害既存の例に化学療法を行なつた場 合，その肝機能に対しいかなる影響を及ぼすであ ろらかということが問題になつてくる。この点に ついては従来ほとんど報告がみられていない，演 者らは肝障害既存例に化学療法が少なくとも 1 週 間以上行なわれ，しかもその前後に肝機能が検査 されている例を選んでretrospectiveに調査し， 肝 機能の変動を追跡してみた. 肝機能変動に一定の 規準を設けて，化学療法前後を比較して，総症例 86例中改善を認めたものは24例 $(27.9 \%)$, 不変が 44例 $(51.2 \%)$ ，悪化が18例 (20.9\%) であつた. この中で基礎疾患が胆石拉よび胆道感染症のもの のみをとりあげてみると，37例中改善18例（48.7 $\%)$, 不変が16例 $(43.2 \%)$, 悪化が 3 例 $(8.1 \%)$ であり,この疾患群では他の疾患群に比して改善 例の多いことが明らかである.

胆石・胆道感染症群について, 化学療法開始前 の肝障害を軽度, 中等度, 高度の 3 群に分け, 化

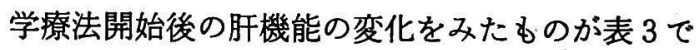
ある. 当初軽度障害群では不変のすのが多く, 中 等度障害群では改善または不変のものが大半を占 め, 高度障害群では改善例が多くみられた．結局 改善例は中等度〜高度障害群に多くみられ; 軽 度〜中等度障害群に不変例が多く, 悪化例は軽度

表 3. Alterations of the liver function during and after the chemotherapy in the biliary infections

Hepatic Impair-

ment prior to the Chemotherapy

slight

moderate

severe

total

$\begin{array}{rr}\text { improved } & \text { NRA } \\ 2 & 7 \\ 10 & 8 \\ 6 & 1 \\ 18 & 16\end{array}$

deteriorated

total

-N.R.A. : no remarkable alterations 
障害群 2 例, 中等度障害群 1 例でいずれも化学療 法中止後正常範囲に回復している。この中の 1 例 は肝毒性既知のTAO (triacetyl oleandomycin) が 投与され，他の 1 例はABPCの使用中E. coliから Klebsiellaに菌交代を起こしたもので，他の1例 はNA，CEZが使用され他の薬剤にも過敏反応を既 往歴に有していた症例である。

胆石・䏣道感染症群以外の群もすべて含めた全 症例について, 各化学療法剂別に肝機能の変動を みると，本調査の範囲内では，とくに一定の薬昘 に悪化例が多いという傾向は認められず，また総 投与量，投与期間との関係についてもとくに有意 の相関関係は認められなかつた。

以上のことから肝障害時，とくに胆道感染症に 肝障害を伴つている例の化学療法においては, 肝 毒性既知の化学寮法剂を避けて，普通投与量を普 通期間使用している限りでは，さらに肝機能を悪 化させることは少なく，むしろ感染症の改善とと もに肝機能も改善される例が多い，しかしながら このような症例に化学療法を行なら場合には慎重 に肝機能を調べながら実施し，もし異常を認めた 場合には速かに減量, 他剂への変更, あるいは投 与中止などの措置をすべきことは勿論である。

\section{V. 急性閉塞性化澧性胆道感染症}

最近の約 3 年間に急性閉塞性化膿性胆道感染症 の6例を経験したので一括して提示する。

症例は表 4 に示すごとく男性 3 例，女性 3 例で 平均年令は70才と高令であり，胆汁性肝硬変の経 過をとつて発症した第 1 例括上び胆石手術後総胆 管十二指腸瘦, 胆道狭窄に上り胆道感染をくり返 した第 6 例のほかは在院期間は約 6 時間から9日 と短く，急激な経過をとり不幸な転㷌をとつてい， る. 臨床的には発熱, 腹部症状（とくに右上腹部 の疼痛), 黄疸, ショック症状括よび意識障害を 主症状とし，原因として全例に胆道結石あるいは 狭窄が認められた。血液の 細菌培養陽性は 4 例 で, 全例にKlebsiellaが陽性, 万ち1例はさらに E. coli括よびClostridium welchii 陽性であつ た. 胆汁培盖ですKlebsiella, E. coliが大多数を占 めそのほかEnterobacter, Citrobacter, Serratia等が おの扣の1例から検出されている.全例に肝機能 異常が認められたが，黄庭は比較的軽度のるのが 多く,しかも初めは気つかれない程度で, 後に明 膫になつてきたものが多かつた。

1 例を除き全例に白血球增多, 核左方推移, 血 沈促進が認められた（表 5 ）。

表 4，化朖性䀒・睅道感染症

\begin{tabular}{|c|c|c|c|c|c|c|c|c|c|c|c|c|c|c|}
\hline \multirow{2}{*}{ 患者 } & \multirow{2}{*}{ 性 } & \multirow{2}{*}{ 年 } & \multirow{2}{*}{ 晦床㖣断 } & \multirow{2}{*}{ 病理䟱断 } & \multicolumn{2}{|c|}{ 稩 菌 培 推 } & \multirow{2}{*}{ 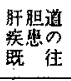 } & \multirow{2}{*}{$\begin{array}{l}\text { 全䅅逼 } \\
\text { (在院日) }\end{array}$} & \multirow{2}{*}{$\begin{array}{l}\text { 発 } \\
\text { 熟 }\end{array}$} & \multirow{2}{*}{ 校部 } & \multirow{2}{*}{ 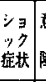 } & \multirow{2}{*}{ 部 } & \multirow{2}{*}{$\begin{array}{l}\text { 黄 } \\
\text { 迫 }\end{array}$} & \multirow{2}{*}{$\begin{array}{l}\text { 檕 } \\
\text { 㤾 }\end{array}$} \\
\hline & & & & & 血液 & 狚 计 & & & & & & & & \\
\hline & 女 & 58 & 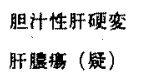 & 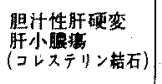 & - & $\begin{array}{l}\text { Klebsiella } \\
\text { E.coli }\end{array}$ & + & $\begin{array}{l}\text { 約 } 5 \text { 年 } \\
(29 \text { 日) }\end{array}$ & + & + & lt & + & + & 死 \\
\hline & 男 & 89 & 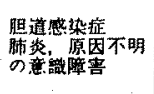 & 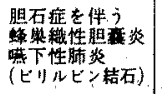 & - & $\begin{array}{l}\text { Entero- } \\
\text { bacter } \\
\text { E.coli }\end{array}$ & - & $\begin{array}{l}11 日 \\
(9 日)\end{array}$ & + & + & + & + & + & 死 \\
\hline & 男 & 63 & 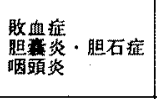 & 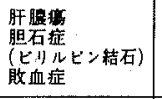 & Klebsiella & Klebsiella & - & $\begin{array}{c}12 \text { 日 } \\
\text { (3日) }\end{array}$ & + & + & + & + & + & 死 \\
\hline & 女 & 86 & 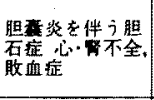 & 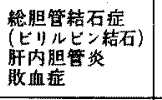 & $\begin{array}{l}\text { E.coli } \\
\text { Klebsiella } \\
\text { Cl.welchii }\end{array}$ & $\begin{array}{c}\text { Klebsiella } \\
\begin{array}{c}\text { Citro- } \\
\text { bacter }\end{array}\end{array}$ & - & $\begin{array}{c}3 \text { 日 } \\
(1.58)\end{array}$ & + & + & $1+$ & + & + & 死 \\
\hline & 男 & 74 & 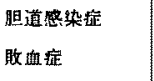 & 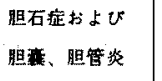 & Klebsiella & Klebsiella & - & $\left(\begin{array}{c}1 \text { 日 } \\
\text { (6时間) }\end{array}\right)$ & + & + & + & + & + & 死 \\
\hline & 女 & 47 & $\begin{array}{l}\text { 胆道感染症 } \\
\text { 敗通症应 }\end{array}$ & 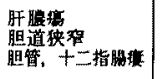 & Klebsiella & $\begin{array}{l}\text { Klebsiella } \\
\text { Serratia }\end{array}$ & + & & + & $1+$ & + & - & + & $\begin{array}{l}\text { 生 } \\
\text { 存 }\end{array}$ \\
\hline
\end{tabular}


表 5. Laboratory findings

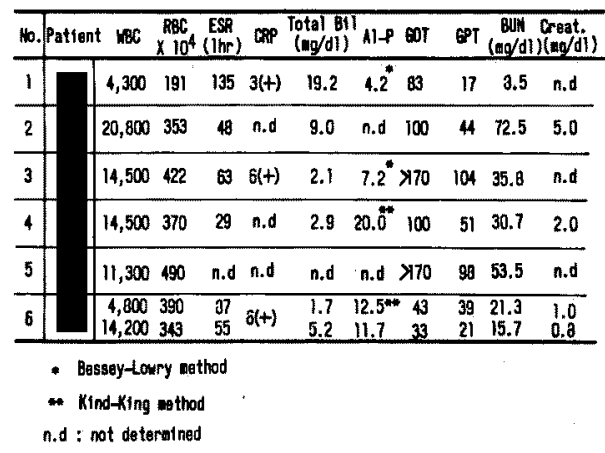

治療はショックに対する処置および広域スペク トルの合成PC系，セファロスポリン系抗生剂に よる化学療法が施行されたが，5例が不幸な転帰 をとり，剖検上全例に胆道結石と，急性肝内胆管 炎を主とする胆道炎があり，3例に大小さまざま の肝膿煌が認められた.ショック経過後の生存例 （第6 例）は化学療法，ステロイドの大量投与の ほかに外科的処置が加えられたものである。

このように胆道感染症のなかでも急性閉塞性化 膿性胆管资ないしは肝膿匐は重䇹な症状を呈し経 過がきわめて急激で，とくに胆道疾患の既往のな い高令者においては鑑別診断が困難な場合があ り，本症の治療上化学療法のみでは限界があるの で・ -12)，早期診断の確立と時期を失しない適切 な胆道減圧処置（主として外科的 T字管ドレナー ジたは経皮経肝胆管ドレナーシ等) が強力な化 学療法, ショックの治療とともにきわめて重要で ある。

\section{まとめ}

胆道感染症の化学療法に際し，1）正確な原因 菌の把握, 2) その化学潦法㓮感受性, 3）化学 療法昘の藏器親和性ないしは胆汁内移行性, 4) 化学療法剤の生体内代謝，5）副作用等が原則的 に重要な留意点であることを，筆者らの調査なら びに実験的成績を加兄て概説した。

またこのような注意をしながら強力な化学療法
を行なつても，しばしばその限界を感じせられ る症例遭遇することも事実であり，その 1 例と して急性閉塞性化膿性胆管炎の症例を供覧した。 一般的には環境条件の变化, 化学潦法の発達によ つて, 化学療法凧の奏効しにくいいわゆるopportunistic pathogensの増加や感染抵抗性の減弱した compromised hostにおける感染の增加も一つの原 因であると考えられるが，上記症例のごとき感染 症の治療に当つて, 強力な化学療法とともに, 早 期診断の確立, ショック対策, 時期を失しない胆 道減圧等の処置が極めて重要である.

な拉，種々の病態を有する宿主においては化学 療法剤の吸収, 排泄, 代謝等の動態が健常な生体 におけるそれとは著しく異なるので，その追究は 単に薬効を求める立場からのみでなく，化学療法 剤の副作用軽減, 安全性保証の点からも重要で今 後さらに検討を重ねる必要がある。

\section{文献}

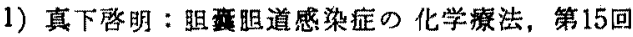
日本医学会総会学術集会記睩 V: 111，1959. 一 2）清水喜八郎：睅衰睅管感染症の化学療法に関寸 百研究。日消誌 $56: 169,1959$ ，一3) 真下警明， 他：䏣道感染症。治療 $47: 1061 ， 1965 .-4)$ Flemma $R$, et al: Bacteriologic studies of biliary tract infection. Ann Surg 166: 563, $1967 .-5$ ) Keighley MRB, et al: Antibiotic treatment of biliary sepsis. Surg Clin North Amer 55(6): 1379, 1975. 一6) 真下啓明：旰上化学療法. 感染症 3:81, 1973, -7) Mortimer PR, et al: Ampicillin levels in human bile in the presence of biliary tract disease. Brit Med J 3: 88, 1969. 8) Brown RB, et al: Penetration of clindamycin phosphate into the abnormal human biliary tract. Ann Inter Med 84: 168, 1976. -9) Andrew DJ, et al: Acute suppurative cholangitis, a medical and surgical emergency. Amer J Gastroenterol 54: 141, 1970. 一10) 菅原克彦, 他：念性化

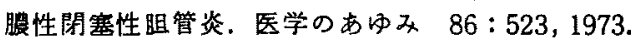
一11）板谷博之：急性閉塞性化服性睅管炎. 日本医 事新報 No. 2720, 16, 1976. - 12) Cacioppo PL, et al: Ascending cholangitis: an urgent surgical problem. Geriatrics 28: 156, 1973. 